\title{
Profile and Antibiotic Sensitivity of Acute Pyelonephritis in Children at Gabriel Toure Teaching Hospital, Bamako
}

\author{
Djénèba Konaté1*, Lala N'Driany Sidibé1, Karamoko Sacko', Bakary Koné1, Adama Koné2, \\ Aminata Doumbia1, Fatoumata Tiero1, Pierre Togo1, Fatouamata Léonie Diakité1, \\ Abdoul Karim Doumbia1, Belco Maiga1, Fousseyni Traoré1, Aamadou Touré1, Hawa Diall1, \\ Mohamed Elmouhouloud Cissé1, Adama Dembélé1, Oumar Coulibaly¹, Yacouba Aba Coulibaly ${ }^{1}$, \\ H. Konaré1, Isabelle Traoré1, Guédiouma Dembélé1, Issiaka Koné1, Leyla Maïga1, \\ Ibrahima Ahamadou1, Abdoul Aziz Diakité1, Boubacar Togo', Mariam Sylla1, \\ Fatoumata Dicko-Traoré ${ }^{1}$
}

${ }^{1}$ Pediatric Department, CHU Gabriel Toure, Bamako, Mali

${ }^{2}$ Pediatric Unit, Hospital Center Mother-Child, Luxembourg, Luxembourg

Email: *djeneba.konate@yahoofr

How to cite this paper: Konaté, D., Sidibé, L.N., Sacko, K., Koné, B., Koné, A., Doumbia, A., Tiero, F., Togo, P., Diakité, F.L., Doumbia, A.K., Maiga, B., Traoré, F., Touré, A., Diall, H., Cissé, M.E., Dembélé, A., Coulibaly, O., Coulibaly, Y.A., Konaré, H., Traoré, I., Dembélé, G., Koné, I., Maïga, L., Ahamadou, I., Diakité, A.A., Togo, B., Sylla, M. and Dicko-Traoré, F. (2020) Profile and Antibiotic Sensitivity of Acute Pyelonephritis in Children at Gabriel Toure Teaching Hospital, Bamako. Open Journal of Pediatrics, 10, 94-108.

https://doi.org/10.4236/ojped.2020.101008

Received: December 20, 2019

Accepted: January 19, 2020

Published: January 22, 2020

Copyright $\odot 2020$ by author(s) and Scientific Research Publishing Inc. This work is licensed under the Creative Commons Attribution International License (CC BY 4.0).

http://creativecommons.org/licenses/by/4.0/ (c) (i) Open Access

\begin{abstract}
Background: Very common symptom in children, fever, perhaps a warning sign of more or less severe pathology, rapidly progressive, including an invasive bacterial infection such as acute pyelonephritis (APN). The aim of this work was to study the bacteriological profile and antibiotic sensitivity of APN in children. Methods: A prospective study involving any infant or child aged 3 months to 15 years with an acute fever $\left(\geq 38^{\circ} \mathrm{C}\right)$ in which a urine test strip was performed in the pediatric department of the teaching hospital Gabriel Toure between April $1^{\text {st }}$ and May 15 $5^{\text {th }}, 2019$ (45 days). Results: 124 children were included out of 244 febrile patients. Infants (3 - 23 months) predominated $(52.8 \%)$ with a sex ratio of 2 . Seventy-five percent of children came directly from home and $30.6 \%$ were on antibiotic prior to admission. The urine bag sample was taken in $55.6 \%$ and the urine was macroscopically cloudy in $32.3 \%$. Stigmas of urinary tract infection at the urinary strip were present in $56.5 \%$. Confirmation of acute pyelonephritis (APN) by CytoBacteriological Urine Examination (CBUE) was $29 \%$ with Escherichia coli (63.9\%) or Enterococcus faecalis (30.5\%). Sensitivity was excellent for ciprofloxacin and imipenem (100\%). The overall resistance was greater for gentamicin, cotrimoxazole, ceftriaxone, cefotaxime and amoxicillin-clavulanic acid (Threshold: $17.9 \%-95.6 \%)$. APN was associated with bacteremia in $2.8 \%$ with hospitalization for $45.2 \%$ and mortality of $11.1 \%$ (due to severe acute malnutrition, severe dehydration and multifocal infection). Conclusion: The APN, daily ac-
\end{abstract}


tivity of pediatrician in Bamako, is observed in one third of febrile children associated with a major life-threatening condition of risk factors, then the likely antibiotherapy could be amikacin in our context.

\section{Keywords}

APN, Fever, Child, Bamako

\section{Introduction}

Fever is an extremely common symptom in children [1]. As the leading cause of consultation in pediatric emergencies ( $15 \%$ to $20 \%$ in developed countries, higher in Africa), fever most often goes with minor and common self-limited infectious diseases [2]. It can be a warning sign of more or less severe and rapidly progressive pathology including an invasive bacterial infection such as acute pyelonephritis (APN).

Febrile urinary tract infection or APN is responsible for $95 \%$ of fever above $39^{\circ} \mathrm{C}$ before 2 years [3]. It is the severe bacterial infection (threatening renal parenchyma with risk of renal scarring or even long-term renal failure) the most common in pediatrics [4].

The diagnostic key remains the Cyto-Bacteriological Urine Examination (CBUE), which must be preceded by a urine test strip (UTS) in any febrile infant. The management of APN is well codified and relies on early and adapted antibiotic treatment.

During 2014 in Caen, 219 cases of PNA diagnosed in children, 18.3\% of which were less than 3 months old and $16.4 \%$ of recent consumption of antibiotics. $\underline{E}$. coli isolated in $80.3 \%$ and E. faecalis in $5.6 \%$. The total sensitivity was $33.5 \%$ to the antiogram [5].

In the pediatric department of the teaching hospital Gabriel Toure, no study was carried out on acute pyelonephritis in children hence the realization of this work was intended, on the one hand, to clarify the bacteriological profile and sensitivity to antibiotics of APN in children.

\section{Methods}

This was a prospective, single-center study that involved infants and febrile children aged at least three months to 15 years of age observed in the pediatric department of CHU Gabriel Toure in Bamako from April $1^{\text {st }}$ to May $15^{\text {th }}, 2019$ (45 days), on whom UTS and CBUE were performed with parents' consent.

Every febrile infant or child admitted to the pediatric department was registered and underwent careful clinical examination. Complementary examinations at the entrance systematically included a urine test strip which when positive for stigmas of a urinary infection (positive leukocytes and/or positive nitrite), has been associated with samples for bacteriological studies (a CBUE \pm a blood culture with culture and antibiogram) and biological (a hemogram, a protein of in- 
flammation CRP). When at the UTS there is no stigma of urinary infection (negative leukocytes and/or negative nitrite), the samples for bacteriological and biological studies of the urinary infection (UI) have not been made. Other examinations (serum creatinine, serum electrolytes, kidney and urinary tract ultrasonography should be) were made according to the context.

Has been considered as:

- Acute fever: any temperature greater than or equal to $38^{\circ} \mathrm{C}$ appeared less than 7 days before admission.

- Urinary bacterial infection: any urine sample after CBUE that meets the following three biological criteria:

- leukocyturia $\geq 10^{4} / \mathrm{ml}$,

- a single bacterial species,

- a bacteriuria in culture whose threshold will differ according to the method of sampling.

* peroral sampling: threshold $>10^{5} \mathrm{UFC} / \mathrm{ml}$.

* sample collection: threshold $>10^{3} \mathrm{UFC} / \mathrm{ml}$.

- APN: any febrile bacterial urinary infection.

Broad-spectrum antibiotic therapy (either mono- or bi-therapy IV or oral monotherapy) was initiated early in case of stigmas in UTS then secondarily adapted according to the antimicrobial susceptibility test. The patient (hospitalized or outpatient) was followed up to 15 days after admission. The criteria of cure were the disappearance of the fever, the normalization of the appearance of the urine after treatment and the amendment of the clinical signs to the admission.

The urine collection method used is that of the middle of the jet for the big child, the self-adhesive pouch for the infant and the small child and the bladder sounding for the comatose children. Each urine received at the laboratory was subject to a cytobacteriological examination and the identification was carried out according to the morphological, cultural and metabolic characters of the germs. The antibiotic resistance test was performed according to the recommendations of the Committee of the antibiogram of the French Society of microbiology (CA-FSM) [6]. The data were collected on a standardized survey sheet previously tested and focused on: the identity of the patient, socio-demographic characteristics of children and their parents, clinical examination, complementary examinations and evolution.

Then, they were entered on SPSS 22.0 and analyzed by using Pearson's Chi2 and Student's $t$ for the different comparisons. The threshold of $\mathrm{p}$ considered significant was set at less than $5 \%$.

\section{Results}

From April $1^{\text {st }}$ to May $15^{\text {th }}, 2019,1908$ children aged between 03 months and 15 years were observed in the pediatric department of the teaching hospital Gabriel Toure and 244 children had at least $38^{\circ} \mathrm{C}$ fever. Of the febrile children, 124 were included in our study, of whom 36 confirmed cases of acute pyelonephritis with a frequency of $29 \%(36 / 124)$. 
Characteristics of children with APN

The sex ratio was 2 (24 boys/12 girls) with a predominance of infants (58.3\%) for an average age of 22 months. Three out of four children came directly from home and almost one-third (30.6\%) were on antibiotics before admission. The clinical picture was dominated by transit disorders $(64.5 \%)$ with its complications: dehydration (17.1\%) and oliguria (6.6\%) Figure 1 . The rest of the characteristics are summarized in Table 1.

Biological characteristics of children

At the hemogram, hyperleukocytosis with polynuclear neutrophils was observed in $50 \%$ of cases, monocytosis (monocytes > 1000 elements $/ \mathrm{mm}^{3}$ ) in $55.6 \%$. C Reactive Protein (CRP) was positive in $84.4 \%$ with an average of $47.70 \mathrm{mg} / \mathrm{l}$ and a maximum of $363.53 \mathrm{mg} / \mathrm{L}$.

Bacteriological characteristics and germ sensitivity

The urine bag sample was taken in $55.6 \%$ and the urine was macroscopically cloudy in $32.3 \%$. The mean leukocyte count was 33,853 leukocytes with a maximum of 580,000 cells $/ \mathrm{mm}^{3}$. Confirmation of APN by CBUE was made in $29 \%$ with presence of Escherichia coli (63.9\%) or Enterococcus faecalis (30.5\%) or Klebsiella pneumoniae (2.8\%) or Enterococcus faecium (2.8\%). Sensitivity was excellent for ciprofloxacin and imipenem (100\%). The overall resistance was major for gentamicin, cotrimoxazole, ceftriaxone, cefotaxime and amoxicillin-clavulanic acid (threshold: $17.9 \%$ - 95.6\%). APN was associated with bacteremia in 06.3\% with hospitalization for $45.2 \%$ for a mortality of $11.1 \%$ (severe acute malnutrition, severe dehydration and urinary and meningeal and urinary and cardiacmultifocal infection).

Antibiotic therapy was subsequently adapted in $58.3 \%$ of cases. Seventy-five percent of the prescribers were physicians in pediatric specialization, $14 \%$ were acting as interns and $11 \%$ were pediatricians.

Table 1 summarizes the characteristics of children with APN.

Seventy-five percent of the prescribers were doctors in the pediatric specialization field. The dual antibiotic therapy Ceftriaxone + Gentacine and Cefotaxime Gentamicine were respectively prescribed in $69.4 \%$ and $19.4 \%$ (Table 2).

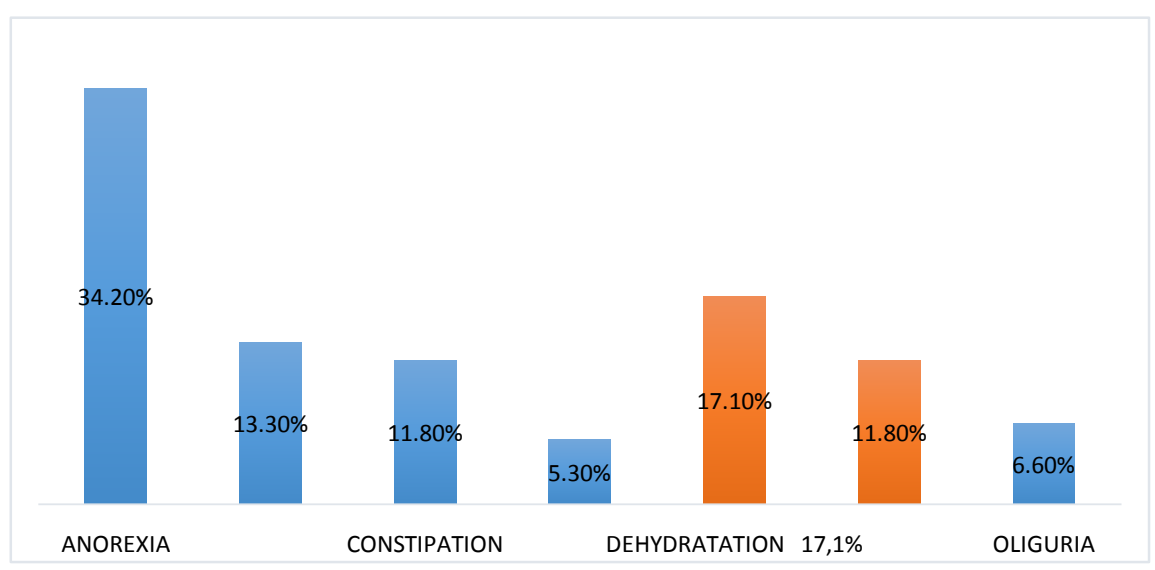

Figure 1. Clinical signs on admission outside fever. 
Table 1. Characteristics of children with acute pyelonephritis.

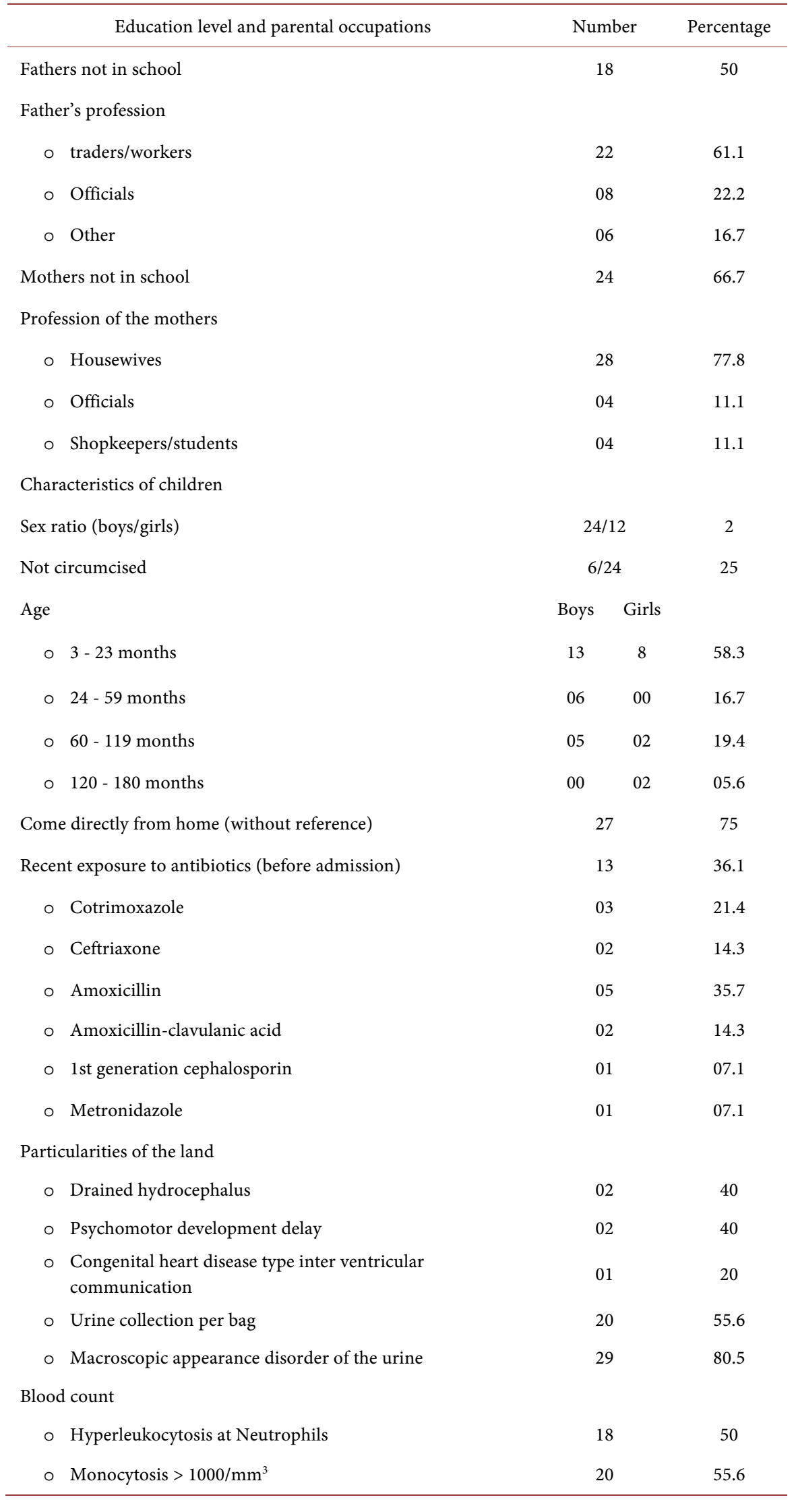




\section{Continued}

\begin{tabular}{lcc} 
CRP & & \\
O Positive & 30 & 84.4 \\
0 Negative & 06 & 15.6 \\
0 Blood culture & $16 / 36$ & \\
O Positive & $1 / 16$ & 06.3 \\
O Negative & $15 / 16$ & 93.7 \\
Number of hospitalized children & 17 & 47.2 \\
Outcome & & \\
O Living & 32 & 88.9 \\
O Death & 04 & 11.1 \\
\hline
\end{tabular}

Table 2. Distribution of children prescriber profile and first-line antibiotic therapy.

\begin{tabular}{ccccc}
\hline Prescriber Profile & Percentage & Antibiotherapy & Number & Percentage \\
\hline Doctors in specialization & 75 & Ceftriaxone + Gentamicin & 25 & 69.4 \\
Pediatric doctors & 11 & Cefotaxime + Gentamicin & 7 & 19.4 \\
DIF & 14 & Cefotaxime & 4 & 11.2 \\
& & Total & 36 & 100 \\
\hline
\end{tabular}

DIF: Doing internal function.

\section{Discussion}

During the study, we encountered certain difficulties:

- the realization of blood culture in certain patients for lack of financial means,

- the non-feasibility of the CBUE during working days after 4 p.m. and on weekends,

- the fairly long deadline for reporting the CBUE results, at least 4 days.

The limits of this work are explained by the fact that most of the patients are not insured (in particular the complementary examinations), our health structure was not equipped with an apparatus performing the ECBU and the unavailability of laboratory technicians.

Cosmopolitan pathology, more common in children, APN, constitutes a diagnostic and therapeutic emergency because of the renal prognosis, updating the local bacteriological profile and sensitivity to antibiotics play a key role in optimizing this therapeutic emergency. Thus, this study has permitted us to determine the place of APN during fever in children at CHU Gabriel Toure and local epidemiological and bacteriological data of APN.

On the epidemiological level:

Our results are consistent with those of similar studies: the APN affects all age groups of children but infants from 03 to 23 months were the most concerned. This could be explained by the sudden weaning done at this age, thus causing 
deficiencies and malnutrition, hence a high vulnerability to infections, particularly acute pyelonephritis [7] [8]. The male predominance in this work noticed from the recruitment of febrile children, seems to be due to the fact that mothers bring their boys more often to the consultation than their daughters. From infancy to school age, boys are the most affected in our series, whereas in adolescence, it's mostly girls.

From the analysis of Table 1, it appears that children with APN come from families whose parents are mostly uneducated with limited purchasing power. These can be decisive in the management (knowledge of the risk factors of a urinary infection, self-medication with antibiotics, diagnostic or even therapeutic delay).

The biological characteristics of children are identical to those described in the literature [9].

On the biological and bacteriological level:

This study revealed a $29 \%$ incidence of APN during fever states in children at Gabriel Touré Teaching Hospital in Bamako.

Enterobacteriaceae dominated the bacteriological profile of APNs including Escherichia coli (63.9\%), the majority species, also reported by several sub-regional and international studies [7]-[13]. This confirms the place occupied by Escherichia coli in urinary tract infections in children. The upward pathophysiology of UI as well as the strong colonization of the perineum by digestive enterobacteria and in particular Escherichia coli, associated with specific factors of uropathogenicity such as $P$. fimbriae bacterial adhesins explain this predominance [5] [14].

In our series, the second most common bacterium was E. faecalis (30.5\%). In this work, we have noted the absence of Proteus mirabilis and Staphylococcus epidermidis, germs found out in APNs in Caen and Vietnam [5] [15].

The study of antibiotic susceptibility of Escherichia coli strains in our series has shown significant resistance rates to the usual antibiotics tested. Our rates are almost similar to those observed in Vietnam but very different from those of Caen including resistance to ceftriaxone, gentamicin and cefotaxime which was all less than 5\% [5] [16].

The low proportion of strains sensitive to the combination amoxicillin-clavulanic acid and sulfamethoxazole-trimethoprim, ceftriaxone, cefotaxime, is the consequence of the pressure of selection due to the massive prescription and the mostly overuse of these antibiotics, as well as cross-transmission of acquired resistance to plasmid determinism [17] [18]. Regarding aminoglycoside antibiotics, amikacin maintains a good position as opposed to gentamicin. The high rate of resistance to ceftriaxone, cefotaxime and gentamicin compromises the use of these probabilistic antibiotics, widely used in the first-line treatment of APN in children. Fluoroquinolones which have a very interesting antibacterial activity are obviously to be proscribed in the child until the end of the growth period, because of joint toxicity, except in case of resistance to other antibiotics where their use remains possible in the big child from 12 years old.

Lethal risk factors include severe malnutrition, severe dehydration and multi- 
focal infection occurring on the ground (trisomy 21, congenital heart disease). Escherichia coli and Enterococcus faecalis were each encountered in $50 \%$ of the deceased children.

The results of first-line antibiotic therapy and antibiogram are grouped in $\mathrm{Ta}$ ble 3 and Table 4.

Phenotypic analysis in our series has also revealed strains of ESBL E. coli (extended-spectrum beta-lactamases). We know that frequent and inappropriate use of antibiotics is a risk factor for the carriage of ESBL-producing bacteria [19]. Like a local study conducted in 2017 on early neonatal bacterial infection in the neonatal unit of the teaching hospital Gabriel Toure of Bamako, where resistance to cephalosporin of 3rd generation and gentamicin was spectacular (from $12.5 \%$ to $100 \%$ ), combined with our results, there is a worrying multi-resistant local ecology in children (from newborn to 15 years old) in both community and

Table 3. Sensitivity of germs on all antibiograms.

\begin{tabular}{|c|c|c|c|c|c|c|c|c|c|c|c|}
\hline \multirow{3}{*}{$\begin{array}{c}\text { Antibiotic } \\
\text { sensitivity tested }\end{array}$} & \multirow{3}{*}{$\begin{array}{l}\text { Total number of } \\
\text { anti-biogram } \\
\text { performed }\end{array}$} & \multicolumn{2}{|c|}{ Overall germs } & \multicolumn{4}{|c|}{$\begin{array}{c}\text { Bacillus Gram Negative } \\
\text { Enterobacteriaceae }(66.7 \%)\end{array}$} & \multicolumn{4}{|c|}{$\begin{array}{c}\text { Cocci Gram Positive Enterococcus } \\
\text { type }(33.3 \%)\end{array}$} \\
\hline & & \multirow[b]{2}{*}{$\mathrm{S}(\%)$} & \multirow[b]{2}{*}{$\mathrm{R}(\%)$} & \multicolumn{2}{|c|}{$\frac{\text { E. coli }}{(63.9 \%)}$} & \multicolumn{2}{|c|}{$\frac{\text { K. pneumoniae }}{(2.8 \%)}$} & \multicolumn{2}{|c|}{$\frac{\text { E. faecalis }}{(30.5 \%)}$} & \multicolumn{2}{|c|}{$\frac{\text { E. faecium }}{(2.8 \%)}$} \\
\hline & & & & S (\%) & $\mathrm{R}(\%)$ & $\mathrm{S}(\%)$ & $\mathrm{R}(\%)$ & $\mathrm{S}(\%)$ & $\mathrm{R}(\%)$ & S (\%) & $\mathrm{R}(\%)$ \\
\hline Penicillin & 24 & 71.1 & 28.9 & 80 & 20 & NT & NT & 33.3 & 66.7 & 100 & 00 \\
\hline Linezolid & 31 & 100 & 00 & 100 & 00 & NT & NT & 100 & 00 & 100 & 00 \\
\hline Ampicillin & 64 & 27.3 & 72.7 & 45.5 & 54.5 & NT & NT & 36.4 & 63.6 & 00 & 100 \\
\hline Ceftriaxone & 36 & 26.9 & 73.1 & 26.1 & 73.9 & 00 & 100 & 81.8 & 18.2 & 00 & 100 \\
\hline Cefotaxime & 34 & 31.4 & 68.6 & 47.8 & 52.2 & 00 & 100 & 77.8 & 22.2 & 00 & 100 \\
\hline Amoxicillin-clavulanic acid & 36 & 04.4 & 95.6 & 17.4 & 82.6 & 00 & 100 & 00 & 100 & 00 & 100 \\
\hline Gentamicin & 35 & 82.1 & 17.9 & 82.6 & 17.4 & 100 & 00 & 63.6 & 36.4 & NT & NT \\
\hline Amikacin & 34 & 97.6 & 2.4 & 90.5 & 09.5 & 100 & 00 & 100 & 00 & 100 & 00 \\
\hline Tigecilline & 35 & 100 & 00 & 100 & 00 & 100 & 00 & 100 & 00 & 100 & 00 \\
\hline Ciprofloxacin & 36 & 100 & 00 & 100 & 00 & 100 & 00 & 100 & 00 & 100 & 00 \\
\hline Imipenem & 35 & 100 & 00 & 100 & 00 & 100 & 00 & 100 & 00 & 100 & 00 \\
\hline Ertapenem & 33 & 100 & 00 & 100 & 00 & 100 & 00 & 100 & 00 & 100 & 00 \\
\hline Tobramycin & 21 & 100 & 00 & 100 & 00 & NT & NT & 100 & 00 & 100 & 00 \\
\hline Streptomycin & 21 & 100 & 00 & 100 & 00 & 100 & 00 & 100 & 00 & 100 & 00 \\
\hline Cotrimoxazole & 33 & 13.2 & 86.8 & 17.4 & 82.6 & NT & NT & 22.2 & 77.8 & 00 & 100 \\
\hline Ticarcillin & 25 & 100 & 00 & 100 & 00 & 100 & 00 & 100 & 00 & 100 & 00 \\
\hline Quinupristin & 6 & 100 & 00 & 100 & 00 & NT & NT & NT & NT & 100 & 00 \\
\hline
\end{tabular}

NB: E. coli: Escherichia coli, K. pneumoniae. Klebsiella pneumoniae, E. faecalis: Enterococcus faecalis, E. faecium: Enterococcus faecium. S: sensitivity; R: Resistance: NT: Not tested. 
Table 4. The main bacteria isolated during pyelonephritis in infants and children in Caen (France), Vietnam and Bamako (Mali).

\begin{tabular}{cccc}
\hline Germs (frequency in \%) & Our study & $\begin{array}{c}\text { A. Flammang et al., 2014 } \\
{[15]}\end{array}$ & HP Duong et al. 2015 [16] \\
\hline$\underline{\text { E. coli }}$ & 63.9 & 80.3 & 80 \\
$\underline{\text { E. faecalis }}$ & 30.5 & 05.6 & 02 \\
$\underline{\text { Kpneumoniae }}$ & 02.8 & 02.6 & 06 \\
$\underline{\text { E. faecium }}$ & 02.8 & 00 & 00 \\
$\underline{\text { Proteus mirabilis }}$ & 00 & 01.7 & 01 \\
$\underline{\text { Enterobacter cloacae complex }}$ & 00 & 01.3 & 00 \\
$\underline{\text { Staphylococcus epidermidis }}$ & 00 & 01.3 & 01 \\
\hline
\end{tabular}

Bamako hospitals. Faced with this, the rules of "good use" and "less use" of antibiotics must be adopted by all health professionals.

\section{Conclusion}

This work has demonstrated the worrying nature of the antibiotic resistance of uropathogenic germs in Bamako. This imposes surveillance of its resistance as well as a rational prescription of antibiotics and with amikacin as probabilistic antibiotherapy of the first intention in our context.

\section{Acknowledgements}

This study was submitted to the approval of CNESS (National Committee of Ethics of Health Sciences) of Mali before the start of activities. The consent and informed consent of the parents or guardian have been obtained. All information obtained was kept confidential and the study documents were stored in a key cabinet to which only the investigators and study coordinators had access under the responsibility of the principal investigator. We, the authors, declare having no conflicts of interest in relation to this article.

\section{Conflicts of Interest}

The authors declare no conflicts of interest regarding the publication of this paper.

\section{References}

[1] National Institute for Health and Clinical Excellence (2018) Fever in Children Younger than 5 Years. https://www.nice.org.uk/nicemedia/pdf/

[2] Crocetti, M., Moghbeli, N. and Serwint, J. (2000) Fever Phobia Revisited: Have Parental Misconceptions about Fever Changed in 20 Years? Pediatrics, 107, 1241-1246. https://doi.org/10.1542/peds.107.6.1241

[3] Gras-Le Guen, C., Levieux, K., Vrignaud, B. and Launay, E. (2018) Acute Infant Fever, Chapter 8 in Pediatric Emergencies. Elsevier Masson, New York. 
[4] DREES (2007) The Care of Children in General Medicine, a Typology of Consultations and Visits. Studies and Results, 588.

[5] Flammang, A., Morello, R., Vergnaud, M., Brouard, M. and Eckart, P. (2017) Study of the Profile of Bacterial Resistance in Pyelonephritis of the Child in 2014. Archives de Pédiatrie, 24, 215-224. https://doi.org/10.1016/j.arcped.2016.12.006

[6] CASFM/EUCAST (2017) French Society of Microbiology. https://www.casfm.org/annual-conference/2017

[7] Garraffo, A., Marguet, C., Checoury, A., Boyer, S., Gardrat, A., Houivet, E., et al. (2014) Urinary Tract Infections in Hospital Pediatrics: Many Previous Antibiotherapy and Antibiotics Resistance, including Fluoroquinolones. Médecine et Maladies Infectieuses, 44, 63-68. https://doi.org/10.1016/j.medmal.2013.12.002

[8] Bouskraoui, M., Ait Sab, I., Draiss, G., Bourrouss, M. and Sbihi, M. (2010) Epidemiology of Urinary Infection in Children in Marrakech. Archives de Pédiatrie, 17, 177-178. https://doi.org/10.1016/S0929-693X(10)70921-0

[9] Lacobelli, S., Bonsante, F. and Guignard, J.P. (2009) Urinary Tract Infections in Pediatrics. Archives de Pédiatrie, 16, 1073-1079.

https://doi.org/10.1016/j.arcped.2009.03.001

[10] Anoukoum, T., Agbodjan-Djossou, O. and Arakouma, Y.D. (2001) Epidemiological and Etiological Aspects of Urinary Tract Infection in Children in the Pediatric Department of the University Hospital of Lome (Togo). Annales d Urologie, 35, 178-184. https://doi.org/10.1016/S0003-4401(01)00024-9

[11] Marzouk, M., Ferjani, A., Haj Ali, M. and Boukadida, J. (2015) Profile and Antibiotic Sensitivity of 1879 Pathogenic Urinary Tract Bacteria Isolated in Children (2012-2013). Pediatrics Archives, 22, 505-509. https://doi.org/10.1016/j.arcped.2015.02.015

[12] Hanna Wakim, R.H., Soha, G.T. and Mona, W.E.H. (2015) Epidemiology and Characteristics of Urinary Tract Infections in Children and Adolescents. Frontiers in Cellular and Infection Microbiology, 5, 45. https://doi.org/10.3389/fcimb.2015.00045

[13] Khursheed, A.W., Mohd, A., Javaid, A.B., Nazir, A.P., Lubna, S. and Sartaj, A.B. (2016) Pediatric Urinary Tract Infection: A Hospital Based Experience. Journal of Clinical and Diagnostic Research, 10, SC04-SC07.

[14] Alvarez, C., Pangon, B., Allouch, P.Y. and Ghnassia, J.C. (1992) Urinary Infections: Main Epidemiological, Bacteriological and Clinical Aspects. Biology Sheets, 33, 15-24.

[15] Larabi, K., Masmoudi, A. and Fendri, C. (2003) Bacteriological Study and Resistance Phenotypes of Germs Responsible for Urinary Tract Infections in a University Hospital Center in Tunis: About 1930 Cases. Médecine et Maladies Infectieuses, 33, 348-352. https://doi.org/10.1016/S0399-077X(03)00180-X

[16] Duong, H.P., Mong Hiep, T.T., Hoang Janssen, F., Lepage, P., De Mol, P., et al. (2015) Management of Febrile Urinary Tract Infections in Vietnamese Children. Pediatrics Archives, 22, 848-852. https://doi.org/10.1016/j.arcped.2015.05.010

[17] Haller, M., Brandis, M. and Berner, R. (2004) Antibiotic Resistance of Urinary Tract Pathogens and Rationale for Empirical Intravenous Therapy. Pediatric Nephrology, 19, 982-986. https://doi.org/10.1007/s00467-004-1528-7

[18] Launay, E., Bingen, E., Cohen, R. and the Pediatric Infectious Pathology Group (2012) Therapeutic Strategies in Urinary Tract Infections of Infants and Children. Archives de Pédiatrie, 19, 109-116. https://doi.org/10.1016/S0929-693X(12)71283-6 
[19] Colodner, R., Rock, W., Chazan, B., Keller, N., Guy, N., Sakran, W., et al. (2004) Risk Factors for the Development of Extended-Spectrum Beta-Lactamase-Producing Bacteria in Non-Hospitalized Patients. European Journal of Clinical Microbiology and Infectious Diseases, 23, 163-167. https://doi.org/10.1007/s10096-003-1084-2

\section{Abbreviations}

APN: Acute Pyelonephritis

UFC: Unit Forming Colony

L: Liter

CBUE: Cyto-Bacteriological Urine Examination

UTS: Urinary Test Strip

CRP: C Reactive Protein

SPSS: Statistical Package for Social Sciences

CA-FSM: Committee of the Antibiogram of the French Society of Microbiology ESBL: Extended-Spectrum Beta-Lactamases 


\section{An Investigation Sheet}

File No/ /phone $\mathrm{No} /$

Date of inclusion in the study/D $/ / \mathrm{M}$ //2019/

\section{GENERAL CHARACTERISTICS OF THE CHILD}

1) Name: First name (s):

2) Age: Date of birth

3) Gender: / $/ 1=$ male 2 female

4) Status of the child/

$1=$ new patient $2=$ Already followed for

5) Rank in siblings/ / $(\mathrm{ex} ; 4 \mathrm{th} / 6)$

6) Provenance: /

$1=$ House 2 = Referred (to be specified ..)

\section{FAMILY HISTORY}

Dad

7) Age of father/ /(in years)

8) Father's education level: /

$1=$ Out of school $2=$ Elementary $3=$ Secondary $4=$ Tertiary

$5=$ Koranic school $6=$ Not specified

9) Father's profession: /

$1=$ Trader $2=$ Civil servant $3=$ Worker $4=$ Farmer $5=$ Pupil $/$ student $6=$ unemployed $7=$ other (to be specified)

Mother

10) Age of mother/ /(in years)

11) Mother's level of education: /

$1=$ Out of school $2=$ Elementary $3=$ Secondary $4=$ Tertiary

$5=$ Koranic school $6=$ Not specified

12) Mother's profession: /

$1=$ Housewife 2 = Shopkeeper $3=$ Civil servant $4=$ Pupil/student $5=$ other (to be specified)

\section{CLINICAL FEATURES}

1) Temperature/ ${ }^{\circ} \mathrm{C} /$

2) Time for onset of fever: /

$1 \leq 48 \mathrm{H} 2 \geq 48 \mathrm{H}$

3) Previous treatment received/

$1=$ none $2=$ antipyretic $3=$ antibiotic $4=$ anti-malarial

Antipyretic 1 ................................ dose ................................... period

Antipyretic 2 dose period

Antibiotic 1 dose period

Antibiotic 2 dose period

Antimalarial 1 dose period 
4) Weight $(\mathrm{kg}) /$ /Size $(\mathrm{cm}) /$ /arterial pressure (mmHg)/

5) Macroscopic appearance of urine/

$1=$ clear $2=$ cloudy $3=$ purulent $4=$ other $($.

6) Urine strip/

$1=$ Positive leukocytes/ /nitrites/ /urine density/

Other stigmata of the UI at the BU

2 = negative

7) Low back pain: yes $\square$ no $\square$

8) Lumbar contact: yes $\square$ no $\square$

9) Chills: yes $\square$ no $\square$

10) Sepsis severe: yes $\square$ no $\square$

11) Impairment of the general condition: yes $\square$ no $\square$

12) Anorexia: yes $\square$ no $\square$

13) Jaundice: yes $\square$ no $\square$

14) Polyuria: yes $\square$ no $\square$

15) Oliguria yes $\square$ no $\square$

16) Digestive problems: yes $\square$ no $\square$

17) Dehydration: yes $\square$ no $\square$

18) Total fever duration (days): ...

19) Favoring factors: yes $\square$ no $\square$ If yes, type: ...

20) In boys, phimosis: yes $\square$ no $\square$, circumcision: yes $\square$ no $\square$

21) History of uropathy: yes $\square$ no $\square$ If yes, type: ...

22) First episode of acute pyelonephritis: yes $\square$ no $\square$

23) Oral hygiene/

$1=\operatorname{good} 2=$ bad (number of decayed teeth ..)

\section{PARACLINICAL CHARACTERISTICS}

urine

1) Method of urine sampling: pocket $\square$ per-voiding $\square$ catheterization $\square$ CBEU

2) Leukocyturia $\square$ account:

3) Other cells:

4) Germ on direct examination $\square$ type: BGN $\square$ CGP $\square$

5) Crops $\square$

Account:

Name of bacteria:

6) Antibiogram yes $\square$ no $\square$

7) Sensitive Intermediate Resistance

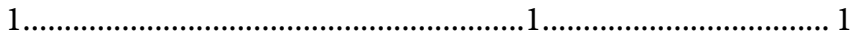

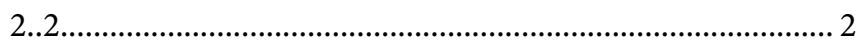

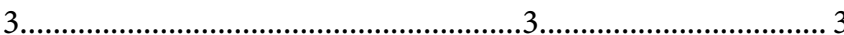

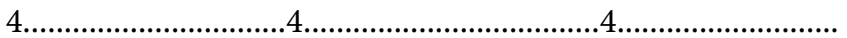

5..5 


\section{Biology}

Inflammation markers

8) CRP: yes $\square$ no $\square$ value $(\mathrm{mg} / \mathrm{l}):$...

9) pct: yes $\square$ no $\square$ value $(\mu \mathrm{g} / \mathrm{l}): \ldots$

Complete blood count

10) Leukocytes $\left(/ \mathrm{mm}^{3}\right)$ : Neutrophils $\left(/ \mathrm{mm}^{3}\right)$

Monocytes $\left(/ \mathrm{mm}^{3}\right)$

11) Hemoglobin (g/dl):

12) pads (giga):

Biochemistry and blood cultures

13) Creatinine: yes $\square$ no $\square$ value $(\mu \mathrm{mol} / \mathrm{l}): \ldots$

14) Blood icon: yes $\square$ no $\square$ if yes normal $\square /$ abnormal $\square$

15) Blood cultures: yes $\square$ no $\square$ if yes, negative $\square$ positive $\square$

(specify the germ

..)

16) Antibiogram yes $\square$ no $\square$

Sensitive $\quad$ Intermediate $\quad$ Resistance

17) Thick drop negative $\square$ positive $\square$

18) Other biological examinations

Imaging yes $\square$ no $\square$

19) Renal and urinary tract ultrasound: yes $\square$ no $\square$

20) If yes injuries: yes $\square$ no $\square$ type:

21) CT scan of the kidneys and urinary tract: yes $\square$ no $\square$

5. RETAINED DIAGNOSIS/

1) $=$ PNA $2=$ others (to be specified)

\section{TREATMENT}

1) Prescriber/

$1=\mathrm{PhD}$ students $2=$ doctors in specialization $=$ Pediatricians $4=$ others $($ to be specified)

2) Total duration of antibiotic therapy (days): ......

3) Hospitalization: yes $\square$ no $\square \quad$ length of hospitalization (days): ...

4) Outpatient treatment: yes $\square$ no $\square$

Parenteral treatment

5) Parenteral ATB duration (days):

6) Ceftriaxone: yes $\square$ no $\square$ dose $(\mathrm{mg} / \mathrm{kg} /$ day): .......................

7) Cefotaxime: yes $\square$ no $\square$ dose ( $\mathrm{mg} / \mathrm{kg} /$ day): $. / \ldots \ldots . . . . . . .$.

8) other antibiotics: type: dose $(\mathrm{mg} / \mathrm{kg} /$ day $)$ : 
9) Gentamicin: yes $\square$ no $\square$ dose (mg/kg/day): $. / \ldots \ldots . . . . . .$.

10) Compliant antibiotics: yes $\square$ no $\square$

Other parenteral drugs

11) antipyretic yes $\square$ no $\square$ (molecules and doses to be specified)

antipyrétique1 dose period

antipyrétique2 dose period

12) anti-malarial yes $\square$ no $\square$ (molecule and dose to be specified) antimalarial dose period

13) other drugs yes $\square$ no $\square$ (molecules and doses to be specified)

molecule 1 dose $(\mathrm{mg} / \mathrm{kg})$ duration

molecule 2 dose $(\mathrm{mg} / \mathrm{kg})$ duration

molecule 3 dose $(\mathrm{mg} / \mathrm{kg})$ duration

molecule 4 dose $(\mathrm{mg} / \mathrm{kg})$ duration

14) Other compliant parenteral drugs: yes $\square$ no $\square$ Oral treatment

15) Antibiotic (ATB) oral treatment: yes $\square$ no $\square$ ATB1 dose $(\mathrm{mg} / \mathrm{kg})$ duration ATB2 dose $(\mathrm{mg} / \mathrm{kg})$ duration

16) Oral ATB duration (days):

17) Other oral treatments: yes $\square$ no $\square$

molecule1 dose $(\mathrm{mg} / \mathrm{kg})$ duration.

molecule2 dose $(\mathrm{mg} / \mathrm{kg})$ duration.

molecule3 dose $(\mathrm{mg} / \mathrm{kg})$ duration

18) Compliant oral treatment: yes $\square$ no $\square$

19) Other types of processing

treatment 1 dose $(\mathrm{mg} / \mathrm{kg})$. duration

treatment 2 dose $(\mathrm{mg} / \mathrm{kg})$ duration.

treatment 3 dose $(\mathrm{mg} / \mathrm{kg})$ duration

\section{EVOLUTION}

Immediate complications

1) abscess: yes $\square$ no $\square$

2) renal failure: yes $\square$ no $\square$

3) High blood pressure: yes $\square$ no $\square$

Exit

1. Exit procedure/

$1=$ healed 2 = lost to follow-up $3=$ deceased

2. Release date/ //2019/

4. Exit diagnosis/ 